\title{
Democratic Reform in Egyptian Universities
}

\author{
AHMED EL-OBEIDY
}

\begin{abstract}
Ahmed El-Obeidy is a professor at the University of Cairo, Egypt. E-mail: elobeidy@hotmail.com.
\end{abstract}

Once the former president Hosni Mubarak was forced to step down in a popular revolt in February 2011, the fight against corruption in the country's higher education has been intensifying. The prodemocracy academics, as in Cairo University and Alexandria University, have been pushing to revoke the regulations of appointment of university leadership positions by government authorities. University presidents were appointed directly by the country's president after obtaining approval from security agencies. Deans and department heads came under the authority of the university presidents and were appointed at their discretion. The prodemocracy academics considered that such regulations make university leaders loyal to the governmental authorities.

\section{UNIVERSITY LEADERS' ELECTION}

In response to the uprising, new arrangements were established to hire new university leaders. Under the new arrangements, presidents of universities are chosen through a system in which representatives select the president, while deans of colleges and heads of departments are chosen through direct voting by faculty members. Representatives to the Electoral College are elected by the 
faculty members of the university's colleges. This is clear departure from how leadership positions were traditionally filled in Egypt.

By the end of 2011, university elections were carried out in Egypt, with more than 90 percent of faculty members voting, according to media reports. The result of the election process was not only unexpected but also shocking to those looking toward democracy and elimination remnants of the previous corrupted regime. Many of the old university leaders were reinstated and retained their positions after the election by the faculties. Election results confused the revolutionists in the ranks and trend. It seems that faculty members voted for incentives and advantages that they were promised rather than transforming the universities and enhancing the role of universities in socioeconomic development. It seems that voting by the faculty members to choose the occupants of leadership positions changed universities to be as syndicates rather than educational and research organizations.

\section{Typical Selection of UNiversities Leaders}

Election is a break from how university presidents and deans are selected in many developed and developing countries. In most cases, selecting university presidents and deans is a long process designed to determine the most-qualified candidates for the positions. The university academic leadership positions are typically chosen by selection committees of experienced academic faculty members and driven by the recognition that the fate of academic programs rests on the quality of their decision. The function of the search committee is to find qualified candidates and establish a short list of the most suitable candidates. The final selection of the university president among the short-listed candidates is the 
responsibility of a board of governance assisted by a faculty advisory committee. Once selected, the president makes all nominations for appointments to other leadership positions under the board of governance.

Under this model, the university's board of governance or of trustees is acting as the supreme governing body of the university. The university bylaws may specify the number of members of the board and how they are to be chosen. Generally, in the US public universities the members of the university boards of governance are selected by the elected state governors on behalf of society. In order for this system to be effective, the selection process of the most-qualified candidates for the leadership positions in the universities requires firmly established institutional organization and good governance.

\section{Democracy AND ACCOUNTABility}

When given the opportunity to exercise democracy and vote for their university leaders, Egypt's universities failed to select candidates based on their qualifications for leadership positions. Without building the capacity of institutional organization and governance, the democratic reforms begun in Egypt's universities cannot be achieved. Breaking the entrenched power structures will need more than election and voting. Establishing a strong and credible selection committee from faculty members is an essential first step for a successful search process for candidates of university leadership positions. Selection committee members that take the broader goal of improving the quality of the university system into account play a major role in the recruitment, interviewing, screening, and evaluating the applicants. Guidelines of selecting candidates for leadership positions must be developed to guide and assist 
selection committees in carrying out their search and selection responsibilities. The guidelines may include criteria for selecting candidates based on their vision for the higher education system. Training on the process of searching, screening, and selecting candidates of university leadership positions, for all those who are involved in the process, needs to be developed.

In addition to the professional development of selection committee participants, other faculty members could be invited to participate in open interview sessions of final candidates-to give them opportunity to meet the candidates and collect information about the candidate's job-related knowledge and skills. An open dialogue with the candidates would increase the involvement of faculty as well as the transparency of the process. Evaluation sheets could even be provided for attendees to submit at the end of each open interview session, to be considered by the selection committee.

The final decision to select the candidate of a leadership position should be the responsibility of the university's boards of governance, which is acting as fiduciaries on behalf of society. University boards of governance may be appointed by the elected president, Parliament or Shura Council (senate).

\section{CONCLUSION}

The demand for change by the pro-democracy academics in Egypt was on the promise to have a positive impact on higher education. Elections have been implemented, and faculty participated in the choice of university presidents, deans, and department heads. However, election is not always the best way to select the most qualified and experienced persons for the university leadership positions. 
Democratic reform in universities should not override accountability. The selection of the university leaders should indeed enhance competitiveness among faculty members and the commitment to the selection process. On the other hand, if our goal is for academic reform and improving higher education and scientific research, in order to have strong impact on socioeconomic developments in Egypt, then we must also improve the process of selecting candidates for university leadership positions. Only through the professional development of all those responsible for the selection process can university in Egypt ensure that they are selecting the most-qualified and experienced university leaders who can make a positive contribution to academic reform and achieve the universities' role in higher education and scientific research. The final decision of selection should be the responsibility of boards of governance in behalf of society. 